\title{
Stephen Jay Gould (1941-2002)
}

Stephen Jay Gould, the world's most renowned palaeontologist, died in New York on 20 May. His death robs the fields of palaeontology and evolution of one of their most provocative thinkers, and millions of readers of an entertaining and astonishingly productive commentator on biology.

Gould was born in New York City, and traced his lifelong interest in palaeontology to an encounter as a fiveyear-old with a dinosaur skeleton in the American Museum there. After obtaining a degree in geology from Antioch College in 1963, he became a graduate student at the museum in the joint programme with Columbia University. He acknowledged the importance of Norman Newell as his advisor and teacher ("the most noble word of all human speech"). In 1967 Gould was appointed assistant professor at Harvard University where he willingly took on the teaching of undergraduate non-majors. Even when he became a household name and was much in demand for public lectures, he continued to teach courses in geology, biology and the history of science at Harvard, where he spent his entire career.

Gould's style of science lecturing was unconventional, and he rejoiced in using illustrations and examples from history and art. He liked to read from historical sources, which he sometimes carried with him, and he could quote swathes of the Origin of Species from memory. He was an eloquent advocate for the importance and rigour of the historical sciences, and railed against the common perception of physics and chemistry as somehow superior in status. His digressions and allusions sometimes challenged the audience - bullet points were not Gould's style. But just as the journey was full of interesting detours, the destination was always worth reaching.

Gould's principal scientific contribution was to the theory of evolution, but he was no stranger to field data. His graduate research was on the evolution of the land snails of Bermuda, on which he continued to work throughout his career, notably in collaboration with geneticist David Woodruff. Gould first detected the phenomenon of morphological stasis punctuated by periods of rapid evolutionary change in the snail Poecilozonites. It was this pattern that he and Niles Eldredge, who identified the same pattern in the Devonian trilobite

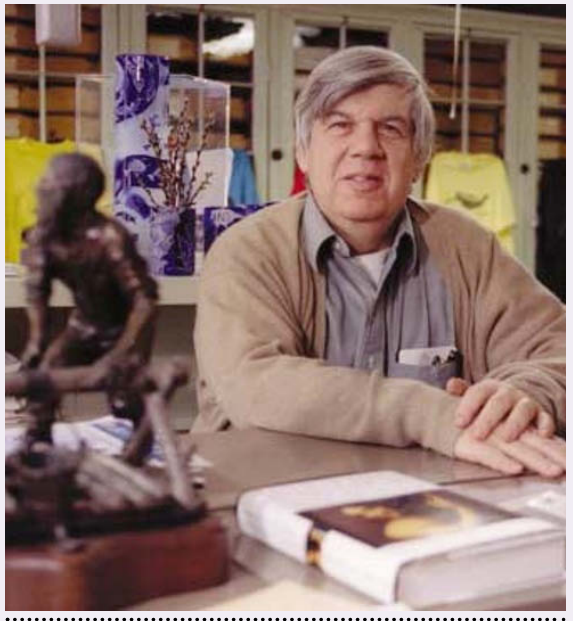

\section{Palaeontologist and public face of evolutionary biology}

Phacops, named 'punctuated equilibrium' in 1972. They contrasted it with 'phyletic gradualism', the gradual transformation of one species into another.

Eldredge and Gould's model provoked a storm of debate, and, like much of Gould's later thinking, stimulated many other researchers, in this case to explore the fossil evidence for the nature of speciation. As Gould and Eldredge wrote in 1993, the "most important implications" of punctuated equilibrium "remain the recognition of stasis as a meaningful and predominant pattern within the history of species, and the recasting of macroevolution as the differential success of certain species (and their descendants) within clades". Thus Gould rejected the reductionist view, championed by Richard Dawkins, that natural selection operates exclusively on discrete genes, but also the idea that selection on individuals in populations is the sole force shaping large-scale evolutionary trends.

Gould's best-known book is probably Wonderful Life (1989), which recounts the story of the reinterpretation of the remarkable animals of the Burgess Shale of British Columbia by Harry Whittington and his students. These fossils are Cambrian in age (over 500 million years old), and Gould's thesis is simple. If the fish-like creature Pikaia, the earliest known chordate, had perished in some Cambrian extinction we, its descendants, would not exist. The evolutionary outcome is contingent on everything that came before. Replay the tape of life and today's biota looks completely different.
Contingency, Gould argued, is a major factor in macroevolution, not least because the response of organisms to catastrophes such as asteroid impacts cannot be predicted - the normal rules of natural selection do not apply. There is no inevitable evolutionary 'progress' to higher forms of life, culminating in man.

Two of Gould's earlier books are scholarly monographs: Ontogeny and Phylogeny (1977) considers the theory of recapitulation (the idea that the evolutionary history of an organism is reflected in the stages of its development) and the Mismeasure of Man $(1981,1996)$ treats measures of human intelligence and their past misuse in ranking racial groups. Between 1974 and 2001 Gould wrote 300 essays under the banner "This view of life" for the magazine Natural History. The tenth and final volume of these collected essays, entitled I Have Landed, was published earlier this year. He was a vigorous opponent of creationism, and particularly the movement to give equal time to creation teaching in schools. These articles are testimony to his commitment to making serious science accessible to a wider audience.

In 1982, Gould was diagnosed with mesothelioma, a rare cancer usually associated with exposure to asbestos. With characteristic intellectual curiosity, he consulted the medical literature and decided that he had a good chance of falling within the tail of the right-skewed distribution of survival times. During his treatment, he never failed to deliver his monthly columns for Natural History magazine. Sadly, 20 years later, he succumbed to a different cancer that had spread before it was detected.

Gould's magnum opus, The Structure of Evolutionary Theory, was published just a few months before he died. Over 20 years in preparation and more than 1,400 pages long, it traces the history of ideas on evolution. Gould considers the main challenges to Darwin: that evolution is hierarchical, operating not only on genes but on species; that natural selection is not the only engine of evolution; and that major perturbations - catastrophic events - influence the fate of groups. He then presents his own synthesis of evolutionary theory in a way that will provoke discussion and research for many years, and serve as a memorial to this remarkable man.

Derek E. G. Briggs Derek E. G. Briggs, Department of Earth Sciences, University of Bristol, Wills Memorial Building, Queen's Road, Bristol BS8 1RJ, UK, is currently on sabbatical in the Department of the Geophysical Sciences at the University of Chicago. e-mail: D.E.G.Briggs@bristol.ac.uk 